\title{
TRAINING NEEDS ASSESSMENT FOR SMALL BUSINESSES: THE CASE OF THE HOSPITALITY INDUSTRY IN JORDAN
}

\author{
Ali S. HYASAT" \\ Al-Balqa Applied University, Deanship of Scientific Research, Al-salt, 19117, Jordan, e-mail: ali.hyasat@bau.edu.jo \\ Ghazi A. AL-WESHAH \\ Al-Balqa Applied University, Department of Marketing, the Faculty of Business, Al-salt, Jordan, e-mail: Ghazi.al-weshah@bau.edu.jo \\ Dana F. KAKEESH \\ The University of Jordan, Department of Marketing, School of Business, Amman, Jordan, e-mail: dana.kakeesh@ju.edu.jo

\begin{abstract}
Citation: Hyasat, A.S., Al-Weshah, G.A., \& Kakeesh, D.F. (2022). TRAINING NEEDS ASSESSMENT FOR SMALL BUSINESSES: THE CASE OF THE HOSPITALITY INDUSTRY IN JORDAN. GeoJournal of Tourism and Geosites, 40(1), 20-29. https://doi.org/10.30892/gtg.40102-798
\end{abstract}

\begin{abstract}
This study is designed to assess and identify the status of hospitality training needs, methods and potential challenges within the hospitality industry, in order to recognize gaps and develop training programmes that address and enhance the competitiveness of small businesses within it. A qualitative approach was employed, whereby face-to-face and semi-structured interviews were conducted with 60 owners and managers of small businesses in the hospitality industry. Using thematic analysis, the study concludes that communication skills, especially foreign languages, are the most the important training need at both managerial and operational levels. Moreover, the study found that on-the-job training is one of the most important training methods. Furthermore, a lack of training budgets is found to be the most critical challenge to training. The study provides empirical evidence and practical implications for decision-makers in the hospitality industry.
\end{abstract}

Key words: labour skills, training needs, small businesses, services, interviews, qualitative approach, hospitality industry, tourism sector, Jordan

\section{INTRODUCTION}

Despite the current negative impact of the coronavirus (Covid-19) on the hospitality industry, there is a still need for hospitality employees to continue learning and training in order to improve guest services. Training programmes for the employees are seen as one of the most important areas in the hospitality industry (Juan, 2017; Baum, 2015; Tracey, 2014). Training for employees is, therefore, vital to ensure quality of service and achieving business goals (Al-Ababneh et al., 2017; Brown et al., 2009). Thus, well-designed training is crucial for any hospitality business. Also, the fact that international guests have multi-cultural backgrounds underpins the urgency for training to prepare employees who are capable of interacting with diverse cultures, religions and ethnicities. Moreover, the quality of service in the hospitality industry does not depend only on location or brand name. It also involves the level of the employee's knowledge - at both practical and theoretical levels; such knowledge should include the employee's attitude, professional customs, respect shown to guests and other skills that are needed to offer better quality service to guests (Brown et al., 2009; Tracey, 2014; Hartline and Ferrell, 1996; Heskett et al., 1997; Sergeant and Frenkel, 2000).

Therefore, employees in the hospitality industry play a major role in delivering service quality as part of small business performance (Al-Weshah, 2018; Juan, 2017; Baum, 2015; Tracey, 2014). Owners and managers of small businesses worldwide should start to recognize the importance of employees for their businesses, and they should acknowledge that more attention must be paid to employees' capabilities in order to empower and enhance their skills to deliver high quality service (Zhao et al., 2004; Rawashdeh, 2018). However, the hospitality industry faces many obstacles and is seen as a most competitive environment where human resources in the tourism environment play a critical role for organizations wishing to succeed with their services and efforts (Juan, 2017; Baum, 2015). Therefore, generating and supporting a competitive advantage through improving employees' skills is a key goal of small businesses in the hospitality industry (Juan, 2017; Al-Weshah, 2019a). To achieve this goal, owners and managers in the hospitality industry need to improve their employees' skills and develop more valued human assets (Rawashdeh, 2018; Kakeesh et al., 2021). Training programmes and practices for employees can be seen as a source of human resources in order to gain some advantage over competitors (Jehanzeb et al., 2013; Al-Weshah, 2017). Within this concept, there is a clear relationship between employees' skills and the need for training programmes (Al-Weshah, 2019a). This kind of relationship can be observed when a training programme improves the skills of employees in the marketplace. It can also be observed when a training programme delivers solutions to the labour market (Baum, 2015).

\footnotetext{
* Corresponding author
} 
Therefore, it is crucial for small hospitality businesses to keep their eyes on the pulse of the skills and training needed to prepare their employees to be competitive in the marketplace (Zehrer and Mössenlechner, 2009; Al-Ababneh et al., 2017). However, there appears to be a large gap between what is essential for employees in the hospitality industry to improve their skills and what can be gained from training centres (Al-Weshah, 2018; Hearns et al., 2007; Barrie, 2006; Kember and Leung, 2005). According to a report buplished by the Jordan Strategy Forum (JSF), most policymakers within the Jordanian hospitality industry consider the industry to be non-professional, and they believe that employees within the industry have limited skills (JSF, 2020). At the same time, most employees view the hospitality industry as a sector which they can enter without skills gained through training (JSF, 2020).

Additionally, the result of these circumstances is a high turnover rate. Yet, the general perception is that jobs in the Jordanian hospitality industry offer no motivation for would-be employees (JSF, 2020). In line with the above, the importance of this paper is to investigate small hospitality businesses in order to highlight gaps and address training needs. Generally speaking, in a dynamic industry such as hospitality, the demand for skilled workers is high (AlKhasawneh, 2013; Al-Ababneh et al., 2017). In addition, the paper is also designed to assist in raising the standard of service quality and boosting competitiveness within the hospitality industry, improving the consumer experience and helping policymakers within the hospitality industry establish and maintain high service standards.

\section{Aims and objectives of the study}

The purpose of this study is to investigate small hospitality businesses and assess their employees' training needs, challenges and methods. Thus, this study acknowledges the gap between current and desired standards and suggests training programmes to bridge this gap and boost the competitiveness of small businesses within the Jordanian hospitality industry. More specifically, the objectives of the study are to:

Assess the training needs in Jordanian small hospitality businesses at both managerial and operational levels;

Explore relevant training methods that can be adopted to improve staff skills in small hospitality businesses;

Identify potential challenges for staff training in small hospitality businesses.

\section{REVIEW OF THE LITERATURE}

\section{Small businesses' perception of training}

In all industries worldwide, human resources play a crucial role in their products in terms of quality and quantity. The service sector, including the hospitality industry, mainly depends on well-trained and educated individuals who work in different types of businesses (Becker and Huselid, 2006; Combs et al., 2006; Paauwe, 2009). Human resources are the most important element of competitive advantage within the hospitality industry. In addition, human resources are an essential feature for hospitality success, both as a means of satisfying ever-increasing customer expectations, and as a way to achieve business profitability (Becker and Huselid, 2006; Combs et al., 2006; Paauwe, 2009; Kakeesh and Ahmad, 2020). Nowadays, providing regular training for employees is one of the best ways to remain competitive in this industry (Fleming et al., 2008; 2009). On the other hand, lack of training, skills and knowledge can lead to a drastic drop in visitor numbers, a decline in repeat business, insufficient tourists for specific markets and attracting only seasonal visitors to specific destinations (Kadiresan et al., 20I5). Within this concept, human resource management (HRM) in any organization should focus on the association between an organization`s HRM systems and its performance (Huselid and Becker, 2010).

The published literature on strategic HRM emphasizes the significant positive impact of high-performance work systems along with employee training (Becker and Huselid, 2006; Combs et al., 2006; Paauwe, 2009). Specifically, research has established that organization performance is improved when training programmes are implemented for employees (Huselid and Becker, 2010). The literature on the hospitality industry also stresses how individual human resource practices can affect organization performance. For example, Tracey and Tews (2004) investigated the impact of training programmes on two measures of organization practice, i.e., employee turnover and sales growth. They collected data from managers and nonmanagerial staff who were working in 22 units of a national restaurant chain. The researchers found that training programmes had a very positive impact on employees who were working in restaurants, in terms of both the organization's performance and the employees' practices (Tracey, 2014; Al-Weshah, 2018). They also found that training programmes delivered to employees reduced employee turnover and increased restaurant sales (Tracey and Tews, 2004). Tracey (2014) also investigated how training programmes delivered to the employees in 16 restaurants and 15 hotels might impact on customer satisfaction. They found that training programmes had a positive impact on customer satisfaction (Tracy et al., 2015).

In line with the above, the management of people aims to obtain a competitive advantage for the organization`s performance and this is exactly what HRM is all about (Becker and Huselid, 2006). One of the most effective human resource practices is training, which is well known as one of the essential practices of HRM, it contributes significantly to organizational competitiveness. Nowadays, organizations within the hospitality industry should concentrate on training practices and activities in order to improve their performance and increase their growth (Rawashdeh, 2018). Also, it has been proven that training increases job satisfaction, and thus loyalty to the company (Chiang et al., 2005). Certainly, employees are described by many researchers as a major asset in any business organization. Overall, it is vital for any business organization to capitalize on training programmes and establish a specialized training department (Kadiresan et al., 2015; Rawashdeh and Al-Adwan, 2012; Ramendram et al., 2014; Kakeesh and Ahmad, 2020).

To this end, training is seen as the most important element for growth that policymakers - within the hospitality industry - should take into account. Such training programmes are crucial and essential for employees in hospitality organizations, as it is described as the most competitive industry within the service sector worldwide (Kadiresan et al., 
2015; Jehanzeb et al., 2013). The benefits to be gained from such training programmes for owners and managers in hospitality organizations include improving and developing their employees and keeping them up-to-date with required skills and knowledge (Ramendram et al., 2014; Lee and Bugler, 2017). Moreover, when a hospitality organization provides employees with training, it contributes greatly to organizational commitment, it improves their skills and competencies, and it provides employees with future opportunities (Kadiresan et al., 2015; Jehanzeb et al., 2013; AlWeshah et al., 2021). On the other hand, employees appreciate the investment of hospitality organizations in training programmes and see it as a sign of loyalty to them (Scheible and Bastos, 2013; Yang et al., 2012).

Table 1. Jobs Generated by Tourism in Jordan, 2019-2021 (Source: USAID Building Economic Sustainability Through Tourism Project, 2020)

\begin{tabular}{|l|c|c|c|}
\hline \multicolumn{1}{|c|}{ Sector } & $\mathbf{2 0 1 9}$ & $\mathbf{2 0 2 0}$ & $\mathbf{2 0 2 1}$ \\
\hline Accommodation & 14,421 & 7,808 & 11,838 \\
\hline Food and Beverage & 19,598 & 10,611 & 16,089 \\
\hline Land and Sea Passenger & 17,538 & 9,496 & 14,397 \\
\hline Air Passenger & 3,793 & 2,053 & 3,113 \\
\hline $\begin{array}{l}\text { Travel Agencies and } \\
\text { Similar }\end{array}$ & 5,112 & 2,768 & 4,197 \\
\hline Entertainment & 4,384 & 2,374 & 3,599 \\
\hline $\begin{array}{l}\text { Other Goods and } \\
\text { Services }\end{array}$ & 32,104 & 17,382 & 26,354 \\
\hline TOTAL & $\mathbf{9 6 , 9 5 0}$ & $\mathbf{5 2 , 4 9 1}$ & $\mathbf{7 9 , 5 8 7}$ \\
\hline
\end{tabular}

\section{The challenges of training in tourism}

As mentioned above, the hospitality industry as service businesses mostly depends upon human resources in order to be successful, pursue business growth and remain competitive (Becker and Huselid, 2006; Combs et al., 2006; Paauwe, 2009). The quality of service in the sector should be of a high standard and must meet customers' expectations (Kadiresan et al., 2015; Rawashdeh and Al-Adwan, 2012). Owners and managers in the hospitality industry must, therefore, take into consideration that they have to keep their employees updated by giving them annual training (Tracey, 2014). However, there are many challenges that managers and owners of small businesses face in developing such training programmes for their employees. The first most common challenge is when managers in small businesses have to develop a training programme for their employees that can meet employee needs and at the same time match their marketplace requirements (Becker and Huselid, 2006; Combs et al., 2006; Paauwe, 2009; Al-Weshah, 2018). Thus, a successful programme should develop training packages that are suitable for employees' needs and cultural differences (Tracey, 2014). Another challenge in developing a training programme in small businesses is that of choosing a trainer, who should be knowledgeable and qualified to prepare material and deliver it effectively to trainees. Another challenge is the ability of a training programme to meet trainees' needs using consistently high-quality materials across sessions, taking into account that more attention must be paid to setting out a list of criteria for the training programme that should be updated from time to time (Kadiresan et al., 2015; Rawashdeh and Al-Adwan, 2012).

Workplace diversity should also be taken into consideration by managers when talking about developing a training programme; issues such as religion, political attitudes, cultural differences and languages among employees might have a (negative or positive) impact on a training programme being developed (Al-Weshah, 2019a). Moreover, the generation gap between employees in the same hospitality business is another challenge that might prevent a training programme achieving its objectives (JSF, 2020; Becker and Huselid, 2006; Combs et al., 2006; Paauwe, 2009). Another common challenge is the high cost of training which may small businesses to embark on cost-cutting or under-investing in training activities (Young-Thelin and Boluk, 2012; Ramendram et al., 2014). This problem is especially relevant for managers in small businesses who believe that it takes time to see actual results of training, as there is no direct return on training which they can use to justify the high cost of training (Kyriakidou and Maroudas, 2010; Young-Thelin and Boluk, 2012; Ramendram et al., 2014). In the case of Jordan, the challenges do not attract people to work in the hospitality industry since they perceive the industry as having relatively low prestige. Another challenge is the cultural differences that make some workplaces, such as hotels and restaurants, an alien and very challenging environment for employees in Jordan (Becker and Huselid, 2006; Combs et al., 2006; Paauwe, 2009; Al-Weshah, 2018).

Moreover, there is low compensation for employees, and most employees in the Jordanian hospitality industry believe that the industry is neither stable nor permanent and does not offer a sustainable career path (JSF, 2020). Low skills in information technology can be seen as one of the major challenges for small businesses in the tourism and hospitality industry (Al-Weshah, 2018). In addition, there is a big difference between what students are taught at university and what are actually skills required by employers in Jordanian hospitality small businesses (Huselid and Becker, 2010). For example, Jordan's workforce and the Jordanian level of education in the hospitality industry are not competitive compared with other countries such as Lebanon and Egypt (JSF, 2020). According to the same report (JSF, 2020), poor HR procedures, unprofessional behaviour, bad hiring decisions and poor selection result in high employee turnover in the Jordanian hospitality industry. Managers and owners must organize regular seminars and training programmes for hospitality HR and communication training workshops (often their behaviour and words affect people 
in a bad way); all these issues will enhance their hospitality knowledge and skills, and they can develop positive attitudes along with all the employees and improve overall performance (Chiang et al., 2005; Lee and Bugler, 2017). Thus, a new approach to partnership between universities and policymakers in the public and private sectors with in the Jordanian tourism industry should be developed. This partnership should be created by the universities, colleagues, tourism stakeholders and the Jordanian hospitality industry in order to provide students and employees in the hospitality industry with the better skills required for it. In addition, this kind of partnership should provide employees in the Jordanian hospitality industry with an applied framework for effective teamwork among industry policymakers (JSF, 2020).

\section{Types of training methods for small businesses}

The literature review revealed that there are weaknesses in the structure and framework of existing training methods (JSF, 2020). Additional efforts are needed to establish new training methods which should focus especially upon small businesses within the hospitality industry. A new framework for organizations should create standardized training methods where the outcomes of such programmes are monitored and evaluated for their effectiveness (Zhao et al., 2004; JSF, 2020). A training methodology should provide a great opportunity for potential employees to gain experience in a particular field or industry, determine if they have an interest in following a particular career, gaining university module credits and creating a network of contacts (Fleming et al., 2008). Training methods may also include the possibility of putting employees or potential employees forward for forthcoming opportunities, after they complete their training programme. Also, part-time work schemes are important for students at university and college by giving them real-life industry experience while getting paid, even though they are not getting any credit hours for their graduation.

Finally, both types of programmes should be equally accessible to both genders (Huselid and Becker, 2010; Fleming et al., 2008; JSF, 2020). Dewhurst et al. (2007) identified the most common different types of training methods used by small business. These can be found in Table 2. Moreover, studies that have investigated different types of training have concluded that there are five main types of training methods that most small businesses use: on-the-job training, computer-based learning, workshops, lectures and seminars, case studies (Dewhurst et al., 2007; Becker and Huselid, 2006; Combs et al., 2006; Paauwe, 2009; Lee and Bugler, 2017).

Table 2. Types of training method programmes (Source: Dewhurst et al., 2007)

\begin{tabular}{|l|l|l|l|l|}
\hline \multicolumn{1}{|c|}{ Training Method } & \multicolumn{1}{|c|}{$\begin{array}{c}\text { Formal or } \\
\text { informal training }\end{array}$} & $\begin{array}{c}\text { External training } \\
\text { or in the workplace }\end{array}$ & $\begin{array}{c}\text { Training provided by } \\
\text { internal or external trainer }\end{array}$ \\
\hline $\mathbf{1}$ & Academic learning & Formal & External/ off-the-job training & External trainer \\
\hline $\mathbf{2}$ & Government training programmes & Formal & External/ off-the-job training & External trainer \\
\hline $\mathbf{3}$ & On-the-job training provided by local educational institutions & Formal & In the workplace & External trainer \\
\hline $\mathbf{4}$ & Employees given on-the-job training & Informal/formal & In the workplace & Internal trainer (in-house) \\
\hline $\mathbf{5}$ & Learning by practice & Informal & In the workplace & Internal trainer (in-house) \\
\hline $\mathbf{6}$ & Private on-the-job training by internal staff & Formal & In the workplace & External trainer \\
\hline $\mathbf{7}$ & Private on-the-job training by external provider & Formal & External/ off-the-job training & External trainer \\
\hline $\mathbf{8}$ & Distance learning & Formal & Workplace/external training & External trainer \\
\hline $\mathbf{9}$ & Electronic-learning & Formal & Workplace/external training & External trainer \\
\hline
\end{tabular}

\section{RESEARCH METHODOLOGY}

\section{Research Approach and Sample}

In this study a qualitative approach was employed, whereby face-to-face interviews were conducted with the targeted sample. Related tourism businesses were chosen to meet the main aims and objectives of the study. There was no list of classified business available at the Ministry of Tourism and Antiquities (MoTA), which led the researcher to adopt a judgmental sample and develop a list based upon their knowledge of the nature of business and its relationship to tourism. Therefore, a judgmental sample of interviewees was selected by the researcher to achieve the study objectives, making sure that all the study`s population was represented. At the beginning 100 participants have been contacted as they gave us initial approval to participate in this study. A qualitative approach was chosen, whereby face-to-face interviews were conducted with the target sample via semi-structured interviews. A judgmental sample was identified amongst tourism and hospitality employers in five geographic areas in Jordan ( $\mathrm{N}=100)$, namely, Amman, As-Salt, Aqaba, Irbid and Petra. The identification process of the sample was as follows. The participants were general managers and owners from different service businesses: 6 general managers from hotels, 14 general managers of traditional restaurants, 20 owners of fast-food restaurants, 20 general managers of coffee shops, 12 owners of herb/ spice shops, 6 general managers of tour operators/ agents, 4 owners of souvenir shops, 10 owners of sweet shops, 4 general managers of guest houses, and finally 4 owners of handicraft shops. The interviewees were purposively selected and contacted by phone to arrange a face-to-face interview. Following this request, an email was sent confirming/ requesting an interview appointment. This procedure continued until the planned sample size was reached from the target population within the five geographical areas. However, due to the Covid-19 pandemic, only 60 interviews $(\mathrm{N}=60)$ were completed. This was done over a period of six weeks and yielded a sample of 60 research participants $(60 \%$ response rate, see Figure 1$)$.

Figure 1 shows the businesses types since it is important to understand the nature of the hospitality businesses represented through the interviews. Thus, the above figure shows that the sum of coffee-shop businesses is 14 in the total sample, followed by traditional restaurants with 11 and 8 for herb/s pice shops. Also, there were 8 sweet shops and 8 fastfood restaurants that took part in the study. Also, interviewees from 4 guest houses, 4 souvenir shops, and 2 handicraft 
shops participated. Finally, there was only 1 tour guide in the selected sample. The researcher interviewed the general managers of fast-food restaurants, coffee shops, tour operators/ agents and guest houses, and the owners of traditional restaurants, herb/spice shops, souvenir shops and sweet shops. However, since this research does not seek to evaluate the state of the Jordanian tourism industry with all its subsectors, a large-scale random sample was not suitable. Instead, the aim was to identify the status of training needs, methods and potential challenges within the hospitality and tourism industry in order to recognize gaps and develop training programmes that address and enhance the competitiveness of small businesses within the industry. The researcher in this study believes that the numbers of the actual sample are representative for this kind of study. Access to the target sample was easy to negotiate as the researcher had already established a good professional relationship with key stakeholders within the Jordanian tourism industry. Moreover, all interviewees in this study were owners of general managers of the businesses ( 34 and 26, respectively).

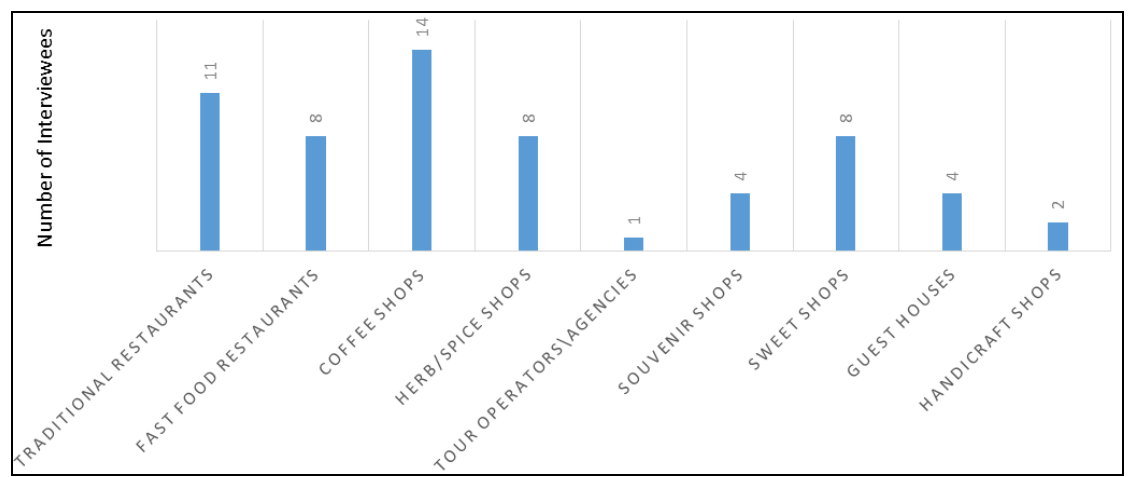

Figure 1.Service Business Type and Number of Participants (Source: developed by the authors)
Table 3. Distribution

of categories over areas/zones (Source: Developed by the authors)

\begin{tabular}{|l|c|c|c|c|}
\hline $\begin{array}{c}\text { Location } \\
\text { activity }\end{array}$ & $\begin{array}{c}\text { Hospi } \\
\text {-tality }\end{array}$ & Tourism & Travel & Total \\
\hline Irbid & 4 & 4 & 4 & 12 \\
\hline Amman & 8 & 4 & 4 & 16 \\
\hline As-Salt & 4 & 4 & $0 *$ & 8 \\
\hline $\begin{array}{l}\text { Petra (Wadi } \\
\text { Musa) }\end{array}$ & 4 & 4 & 4 & 12 \\
\hline Aqaba & 4 & 4 & 4 & 12 \\
\hline Total & 24 & 20 & 16 & 60 \\
\hline
\end{tabular}

* As-Salt City does not have any travel agencies

\section{Data interpretation and presentation}

To analyze qualitative data, a textual and thematic analysis technique was utilized to handle and screen the data, then conduct a comprehensive analysis (Al-Weshah, 2019b). Also, a cross-interview analysis technique was used to develop different themes based on the interviews (Al-Weshah, 2018). The results were handled qualitatively using previously determined fields for discussion. The discussion includes listing the perspectives of stakeholders summarized in tables. The interpretation of general trends is discussed in depth to raise different issues that affect developing training programmes and enhancing the competitiveness of small businesses within the hospitality and tourism industry. In presenting the findings, great care has been taken to ensure that where a quotation is used, this is done to illustrate the main thrust of the analysis and bring clarity to the concepts being represented. On the few occasions where a quotation represents an atypical or idiosyncratic view, this is made clear. When presenting quotes, the interview number is shown at the top of each quote. The participants' own words are presented verbatim, using direct quote marks. However, there is some clarification to ensure normal speech. This is not considered to have any detrimental effect.

\section{Interview format}

Semi-structured interviews were conducted based on purposive sampling. The population of this survey was divided into three categories depending on enterprise classification and size: hospitality, tourism and travel. Moreover, the sample was also divided into five main geographic areas/ zones: Irbid, Amman, As-Salt, Petra and Aqaba. A purposive sample from the above categories was targeted in each area (Table 3). In terms of hospitality, the researcher used a random sampling technique ( $40 \%$ of the total population), which resulted in 24 participants. In terms of the other two categories (tourism and travel), the researcher also used a random sampling technique which was $60 \%$ of the total population within the two mentioned categories in all areas, as shown in Table 3. Each interview was in two main parts; the first part related to general information, this included questions related to demographic data such as interviewee position, type of business, interviewee being an owner or manager, gender diversity of employees (male or female), and employees' age groups. The second part of the interview comprised study questions. The first group of questions covered training needs and requirements. The questions were specific to whether businesses are interested in providing training for their employees, this group included the following topics: Customer Relations, Communication Skills (Foreign Languages), IT skills, Tour Guiding, Leadership, Marketing, Financial, Services, Human Resources and Food Services Management. The second group of questions covered methods and challenges/ barriers as identified by the businesses, this included the following topics: Training methods assessment at the managerial and operational levels, training methods in small hospitality businesses and training challenges/ barriers in small hospitality businesses. The total number of survey questions was $\mathrm{N}=15$, this was divided into two groups in the survey, the first group contained $\mathrm{N}=11$ questions, while the second group contained $\mathrm{N}=4$ main questions, as mentioned above. The interviews were conducted personally by the researchers; the interview schedule was developed based on some previous studies and reports (Dewhurst et al., 2007; Kadiresan et al., 2015). Moreover, the interview schedule was also updated after discussions with some experts in the area. Each interview lasted for 25-30 minutes.

\section{Findings}

Demographic data of interviewees

The following four figures provide a representation of the interviewees' demographic data. As shown in Figure 2, 
$70 \%$ of the interviewees (42 participants) were male, while $30 \%$ of them were females (18 participants). This indicates that there is no relevant diversity for employees in terms of gender. Figure 3 and figure 4, below, show the interviewees who participated in the study in terms of educational levels and experience in years.

\section{Analytical framework}

The interviewees were asked almost the same questions but slightly modified based on their background and level of management. Based on data screening and thematic analysis, the study came up with four main themes, specifically, training needs assessment at the managerial level, training needs assessment at the operational level, the training methods adopted, and potential training challenges in small hospitality businesses. These themes are analyzed in detail using a cross-interview analysis approach (Al-Weshah, 2019a; Al-Weshah, 2019b).

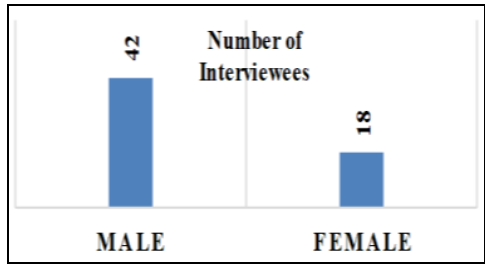

Figure 2. Interviewees' Gender (Male/ Female), (Source: developed by the authors)

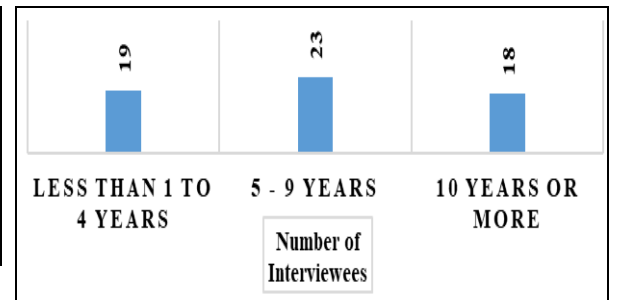

Figure 3. Experience in Years (Source: developed by the authors)

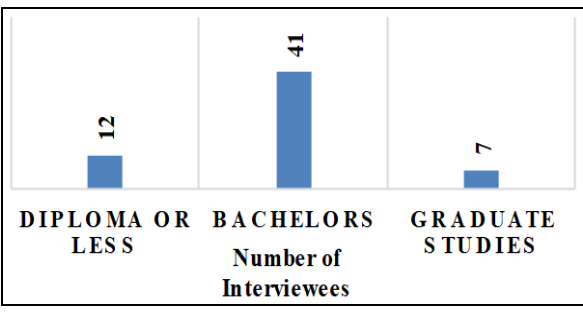

Figure 4. Educational Level

(Source: developed by the authors)

\section{Training needs at the managerial level in small hospitality businesses}

The interviewees were asked to identify training needs areas at the managerial level, their answers are shown in the following table. As shown in Table 4, more than $50 \%$ of interviewees stated that the most crucial training need at the managerial level in small tourism business is communication skills (especially spoken foreign languages), as mentioned by 11 and 12 interviewees, respectively. For example, interviewee No. 4 stated that:

"We need more training in building long-term customer relations, effective communication skills, and human resource services"

Table 4. Training needs assessment at the managerial level, (Source: Developed by the authors)

\begin{tabular}{|l|l|c|}
\hline \multicolumn{1}{|c|}{ Training needs area } & \multicolumn{1}{|c|}{ Interviewee Nos. } & $\begin{array}{c}\text { Total number of interviewees } \\
\text { who mentioned this need }\end{array}$ \\
\hline Customer relations & $1,4,5,6,11,13,14,17,20,22,23,24,27,31,33,34,42,45,50,55,57$ & 21 \\
\hline $\begin{array}{l}\text { Communication skills } \\
\text { (foreign languages) }\end{array}$ & $\begin{array}{l}|c| \\
\text { IT } 5,6,8,11,13,14,15,16,17,20,22,23,24,25,26,27,30,32,33,35,\end{array}$ & 33 \\
\hline IT skills & $8,40,42,43,45,50,52,54,55,57,58,60$ & 12 \\
\hline Tour Guiding & $3,5,8,10,12,15,16,21,28,29,34,40,42,45,48,53,55$ & 18 \\
\hline Leadership & $6,10,14,15,16,26,28,31,34,41,42,46,48,53$ & 15 \\
\hline Marketing & $1,3,5,7,9,11,12,14,15,16,18,20,21,25,26,27,30,32,33,36,39,40$, & 31 \\
\hline Financial services & $41,43,45,49,52,53,55,56,59,60$ & \\
\hline Human resources & $3,9,13,15,16,26,28,32,38,40,42,44,47,55$ & 14 \\
\hline Food service management & $4,8,16,17,20,24,28,33,38,41,42,45,52,57$ & 11 \\
\hline
\end{tabular}

Interestingly, marketing skills are classified in the second rank of training need areas at the managerial level in small tourism business. On the other hand, human resource services and IT skills are the least important training needs areas at the managerial level in small tourism business. Interviewee No. 53 expanded on this point, saying that:

"The most important skills in our business are leadership skills, tour orientation, computer skills, and marketing skills"

These findings are supported by the notion that high-performance systems have a huge impact on the overall performance of the organization (Becker and Huselid, 2006; Combs et al., 2006; Paauwe, 2009). Thus, service quality standards should be high and must meet customers' expectations and lead to their satisfaction (Kadiresan et al., 2015; Rawashdeh and Karim Al-Adwan, 2012).

\section{Training needs at the operational level in small hospitality businesses}

The interviewees were asked to identify training needs areas at the operational level, their answers are shown in the following table. As shown in Table 4, and as stated by 40 interviewees, the most important training needs at the operational level in small tourism business are communication skills (especially spoken foreign languages) and customer services, respectively. On the other hand, the least important training need at the operational level in small tourism business is communication skills (foreign languages). Training needs at the operational level were highlighted by interviewee No. 8 who stated that:

"We have to focus on improving some skills in staff training in our guesthouse such as customer service, foreign languages, tour guiding and hospitality skills.'

Moreover, interviewee No.12 stressed that: 
“Waitering and catering skills along with tour guiding are common areas for training that we need in our restaurant."

These findings are supported by Kadiresan et al. (2015) and Rawashdeh and Al-Adwan (2012) who stress that employees are considered a key asset of an organization. Therefore, it is vital for organizations to invest in them.

\section{Training methods in small hospitality businesses}

The interviewees were asked to identify proposed training methods; their answers are shown in the following table.

As shown in Table 5, and as stated by 37 interviewees, the most common training method adopted for staff is on-the-job (OTJ) training. Meanwhile, the least important training method adopted for staff training small tourism business is exchange visits with other experienced businesses, being mentioned by only 11 interviewees. For example, interviewee No. 1 commented on training methods, saying that:

"Continuous training on the job and regular classes and meetings are critical methods to develop our staff skills."

While interviewee No. 28 mentioned that:

"We prefer to use different training methods such as internal meetings and seminars, funded training by regional and international agencies, and some exchange experience and visits."

These findings are supported by the work of Dewhurst et al. (2007), Becker and Huselid (2006), Combs et al. (2006) and Paauwe (2009), who mention that there a number of training methods that most small businesses use, such as OTJ training, computer-based learning, workshops, lectures and seminars and case studies.

Table 5. Training needs assessment at the operational level (Source: Developed by the authors)

\begin{tabular}{|l|l|c|}
\hline Training needs area & \multicolumn{1}{|c|}{ Interviewee Nos. } & $\begin{array}{c}\text { Total number of interviewees } \\
\text { who mentioned this need }\end{array}$ \\
\hline Customer services & $2,3,4,5,7,8,10,11,13,14,15,16,19,20,21,23,24,25,26,29,30,31,33,35,36,37,40$, & 38 \\
& $41,43,44,45,48,51,52,54,55,58,59,60$ & 40 \\
\hline Communication skills & $1,3,4,5,6,8,10,11,13,14,15,16,17,18,20,21,23,24,25,27,29,30,32,33,35,36,38$, & \\
(foreign languages) & $40,42,43,44,45,49,50,52,54,55,57,58,60$ & 14 \\
\hline IT skills & $1,7,14,15,19,26,29,37,40,42,43,49,53,57$ & 17 \\
\hline Tour Guiding & $3,5,8,10,12,15,21,28,30,35,41,45,48,53,55,56$ & 15 \\
\hline Housekeeping & $2,6,13,16,18,28,29,31,33,37,39,41,44,48,51,53,59$ & 28 \\
\hline Hospitality skills & $1,4,5,6,8,9,11,12,15,19,20,22,24,25,28,30,31,34,36,39,42,45,48,50,54,55,59,60$ & 23 \\
\hline Waitering Skills & $2,4,5,7,10,12,14,17,20,23,24,27,30,32,34,37,42,46,48,53,55,56,58$ & 25 \\
\hline Catering Skills & $1,4,5,7,9,10,12,15,19,20,22,24,28,30,31,34,36,42,45,48,54,55,57,58,60$ & 13 \\
\hline First aid & $6,11,14,18,28,29,33,37,38,41,44,49,51,53,57$ & \\
\hline
\end{tabular}

Table 6. Training methods (Source: Developed by the authors)

\begin{tabular}{|l|l|c|}
\hline \multicolumn{1}{|c|}{ Training method } & \multicolumn{1}{|c|}{ Interviewee Nos. } & $\begin{array}{l}\text { Total number of interviewees who } \\
\text { mentioned this particular method }\end{array}$ \\
\hline On-the-job training & $\begin{array}{l}|c| \\
1,3,4,5,6,8,10,11,13,14,15,17,19,20,21,23,24,25,27,29, \\
30,31,34,35,36,38,40,41,43,44,45,49,51,53,54,55,56,60\end{array}$ & 24 \\
\hline In-house classroom and seminars & $\begin{array}{l}1,2,5,7,9,10,12,16,18,20,22,24,28,30,31,33,37,42, \\
45,48,53,56,57,59,60\end{array}$ & 25 \\
\hline $\begin{array}{l}\text { National institutes for tourism } \\
\text { training }\end{array}$ & $\begin{array}{l}2,4,5,8,10,12,14,17,20,23,24,27,31,32,36,37,41,46, \\
47,54,55,57,58\end{array}$ & 16 \\
\hline $\begin{array}{l}\text { Regional institutes for tourism } \\
\text { training }\end{array}$ & $3,6,8,10,12,15,23,28,30,33,40,45,53,55,56$ & 18 \\
\hline $\begin{array}{l}\text { International institutes for } \\
\text { tourism training }\end{array}$ & $3,6,8,10,12,15,16,21,28,29,30,34,41,42,45,48,53,57$ & 11 \\
\hline Exchange visits & $7,12,14,18,28,29,33,36,47,51,53$ & \\
\hline
\end{tabular}

Training challenges/ barriers to small hospitality businesses

The interviewees were asked to explore the potential challenges of training, their answers are shown in the following table. As shown in Table 6, and as stated by 41 interviewees, the most common training challenge is lack of a training budget; 29 interviewees reported that there is a clear gap between academic learning of tourism and actual needs of the sector. For example, interviewee No. 5 claimed that:

"One of the most important challenges for our staff training is the high cost of training for some specialized skills."

Moreover, interviewee No. 20 claimed that:

"Our business faces many training challenges, such as a small training budget, a practical gap for fresh graduates.”

In line with the previous interviewee, interviewee No. 43 said that:

"We (as hospitality service providers) cannot empower our employees due to many barriers, such as lack of training awareness by our management and lack of available time for our busy staff."

These findings are supported by Huselid and Becker (2010) who found that there is a big difference between what students are taught at university and what is actually required by employers in small business. The finding is also supported 
by Ramendram et al. (2014) who state that organizations that do not offer training programmes because they consider it to be a demonstrative problem and an economic burden on them. Also, this is supported by the findings of Kyriakidou and Maroudas (2010), Young-Thelin and Boluk (2012), Ramendram et al. (2014), who found that small businesses underinvest in training activities and embark on cost-cutting when it comes to training needs assessment.

Table 7. Training challenges (Source: Developed by the authors)

\begin{tabular}{|l|l|c|}
\hline \multicolumn{1}{|c|}{ Training challenge } & \multicolumn{1}{|c|}{ Interviewee Nos. } & $\begin{array}{c}\text { Total number of interviewees } \\
\text { who mentioned this challenge }\end{array}$ \\
\hline Lack of training budget & $1,2,3,4,5,6,8,10,12,13,14,15,18,19,20,22,23,24,25,27,28,30$, & 41 \\
\hline Lack of effective training & $31,33,34,35,36,38,40,41,43,44,45,48,49,52,53,54,55,56,57,60$ & 14 \\
\hline Training time & $2,7,12,16,18,27,29,32,36,38,41,44,47,52,53,58$ & 15 \\
\hline $\begin{array}{l}\text { Gap between academic } \\
\text { curriculums and actual needs }\end{array}$ & $1,4,5,6,8,19,11,12,15,19,20,22,24,25,28,30,31,34,36,39,42$, & 29 \\
\hline Lack of training awareness & $1,5,13,16,19,21,23,25,29,30,31,36,39,41,42,43,48,50,52,57$ & 17 \\
\hline
\end{tabular}

\section{CONCLUSIONS AND PRACTICAL IMPLICATIONS}

The purpose of this study is to investigate small hospitality businesses and assess their employees' training needs, challenges and methods. Thus, this study recognizes the gap between the current standing and the desired one and suggests training programmes that bridge this gap and enhance the competitiveness of small businesses within the Jordanian hospitality industry. To achieve this end, a qualitative approach was employed, whereby face-to-face interviews were conducted with a number of owners of small hospitality businesses. Also, a textual and thematic analysis technique was utilized to handle and screen the data collected, then conduct a comprehensive analysis. The first objective was to assess training needs in Jordanian small hospitality businesses at both the managerial and operational levels. The study found that the top training needs at the managerial level are communication skills (foreign languages), marketing skills, food service management and customer relations, while the top training needs at the operational level in small hospitality businesses are hospitality skills, catering skills and waitering skills.

The second objective was to explore relevant training methods that can be adopted to improve staff skills in small hospitality businesses. The study found that a greater focus should be placed on training methods, mainly hands-on training methods. It also found that seminars and workshops within the hospitality business services are essential as they are considered effective methods to boost employees' skills. Also, it is highly recommended to form some partnerships with national training institutes. Thus, the most important training methods recommended by study are a focus by hospitality service businesses on on-the-job training, in-house classrooms and seminars and national institutes for tourism training.

The third objective was to identify potential challenges to staff training in small hospitality businesses. The findings reveal that the top training challenges that should be given careful consideration are lack of a training budget and the gap between the academic curriculum and actual needs. The study identified a number of training challenges in small hospitality services that managers should pay more attention to overcome them. One of the recommendations is to develop a budget that is appropriate and matches training needs and requirements. Also, it is highly recommended to bridge the gap between education and the labour market through building partnerships with universities and collaborating with educational institutes in order to provide decision-makers with insights into the latest market trends, labour-market needs and qualifications. The fourth objective was to make some recommendations and highlight practical implications for small hospitality businesses. The findings of the current study provide some key insights associated with training needs assessment, training methods and training challenges in small tourism businesses.

First of all, clear and specific training objectives must be specified for tourism training programmes. Also, training needs assessment should be an ongoing process in order to stay up-to-date with current and upcoming trends, and thus meet customers' expectations and retain them as loyal customers. Another recommendation for small hospitality businesses is to adopt personal development plans. This can be accomplished by implementing a follow-up mechanism, having formal off-the-job development programmes, training workshops and a competence-based approach.

Moreover, the use of personal development plans is acknowledged and stated within the literature on training and development as a critical practice to identify training needs and facilitate learning and training. Finally, it is recommended that training programmes are associated with employee promotion so that training boosts employees' job satisfaction and motivation, which results in better performance. It is also important to assign sufficient financial resources in order to provide updated and participatory training materials to employees.

\section{Practical implications}

Important procedures can be adopted by small businesses to assess and provide relevant training to employees according to their needs and the nature of their jobs. Training programmes should be based on employee promotion; accordingly, training helps to motivate employees, which results in better performance. As some Jordanian business have a limited training budget, it is important to provide adequate training courses for employees free of cost or with a minimum charge by different governmental organizations or funded training by international tourism and development NGOs. Also, it is advisable to form partnerships with these NGOs and governmental organizations to maintain sustainable long-term collaboration. Another effective strategy to reduce training costs and address the work pressure on employees is to change the culture, so small businesses should promote the ideas of teamwork, peer-to-peer skills and 
knowledge-sharing and improve employees' interpersonal communication. It is also necessary to select training methods that are digestible and easy-to-apply for employees at the same time, so that small businesses can encourage their employees to become more engaged with training, such as having on-demand courses which employees can take at their convenience. Similarly, businesses might find governmental or non-for-profit organizations and institutions that have online and offline platforms that offer programmes and several courses for free, such as Edraak, Do it, Jordan Chamber of Commerce and The American Chamber of Commerce in Jordan, and thus small businesses can become involved in strategic partnerships with these parties. Many necessary steps should be taken to ensure that training methods are appropriate for employees' capacity. This can be achieved by getting feedback from employees or trainers.

Also, through having clear KPIs to measure improvements in employee performance, e.g. reducing the number of customer complaints by $5 \%$ or increasing the number of processed orders by $10 \%$, and so on. In addition, clear intended learning outcomes should be incorporated into any training programmes. These ILOs will assist businesses to achieve their KPIs. Also, some training assessment systems can be implemented to help small businesses determine their training requirements and select potential employees to participate in training according to the requirements of each training programme without any nepotism or discrimination in terms of trainees' gender, race or nationality.

Another recommendation is to have a flexible training timetable which can be achieved by running some training online or developing recorded training programs to be followed by employees at their convenience. As a result, employees will become more motivated to participate in training programmes without affecting their job responsibilities. Many procedures can also be adopted to follow up and monitor employees' performance and how received training has affected their productivity. This can be achieved, as mentioned before, by linking objectives with KPIs that measure the effectiveness and productivity of training in quantifiable terms. Finally, training allowances and incentives can be provided to motivate employees to take part in future training. For example, businesses should develop data-centric processes via which they can track the performance of each employee and their progress.

This includes, but is not limited to, the number of courses and training session each employee has enrolled in, how many courses he or she has completed successfully, and how courses and training taken are reflected in their performance; and based on that, he or she will get some sort of reward.

\section{Limitations and future research}

There are a number of limitations to this study. The first potential limitation is the possible lack of generalizability of the findings, since the study is limited to small hospitality businesses in Jordan. Thus, comprehensive future research is required on different small businesses in different service sectors, such as finance, banking and travel, and any other similar industries. Another recommendation is perhaps to run a comparative study on different service industries. Moreover, in this study, a qualitative approach was employed with semi-structured interviews; therefore, future studies could adopt a quantitative analysis and hypotheses testing approach that might further increase the understanding and assessment of relevant training needs. Also, using focus groups and questionnaires as data collection methods in future studies could be fruitful.

\section{REFERENCES}

Al-Ababneh, M., Al-Sabi, S., Alshakhsheer, F., \& Masadeh, M. (2017). The influence of employee empowerment on employee job satisfaction in five-star hotels in Jordan. International Business Research, 10(3). 133-147. https://doi.org/0.5539/ibr.v10n3p133

Al-Khasawneh, A.L. (2013). Effect of organizational climate on job turnover of employees at tourism hotels in Petra region of Jordan. American Journal of Social and Management Sciences, 4(2), 54-62. https://doi.org/10.5251/ajsms.2013.4.2.54.62

Al-Weshah, G. (2019a). Organisational excellence as a marketing tool: Greater Amman Municipalityas a case study. Int. J. Business Performance Management, 20 (2), 110-129. https://doi.org/10.1504/IJBPM.2019.098635

Al-Weshah, G. (2019b). The current status of customer relationship management: experience of small businesses in Jordanian food industry. International Journal of Electronic Customer Relationship Management, 12 (1).1-20. https://doi.org/10.1504/IJECRM.2019.098975

Al-Weshah, G. (2018). E-marketing practices from Jordanian tourism agencies perspectives: a qualitative evidence. International Journal of Online Marketing (IJOM), 8(1), 21-36. https://doi.org/10.4018/978-1-7998-2469-5.ch066

Al-Weshah, G. (2017). Marketing intelligence and customer relationships: empirical evidence from Jordanian banks. Journal of Marketing Analytics, 5(3/4), 141-152. https://doi.org/10.1057/s41270-017-0021-7

Al-Weshah, G.A., Kakeesh, D.F., \& Al-Ma'aitah, N.A. (2021). Digital marketing strategies and international patients' satisfaction: an empirical study in Jordanian health service industry. Studies of Applied Economics, 39(7). https://doi.org/10.25115/eea.v39i7.4811

Barrie, S. (2006). Understanding what we mean by the generic attributes of graduates. Higher Education Research and Development, 51(2), 215-241. https://doi.org/ 10.1007/s10734-004-6384-7

Baum, T. (2015). Human resources in tourism: Still waiting for change?-A 2015 reprise. Tourism Management, 50(2015), $204-212$. https://doi.org/10.1016/j.tourman.2015.02.001

Becker, B., \& Huselid, M. (2006). Strategic human resources management: where do we go from here?. Journal of Management, 32 (6), 898-925. https://doi.org/10.1177/0149206306293668

Brown, S.C., Mason, C.A., Lombard, J.L., Martinez, F., Plater-Zyberk, E., Spokane, A.R., Newman, F.L., Pantin, H., \& Szapocznik, J. (2009). The relationship of built environment to perceived social support and psychological distress in Hispanic elders: The role of eyes on the street. Journal of Gerontology: Social Sciences, Series B, 64(2), 234-246. https://doi.org/10.1093/geronb/gbn011

Chiang, C.F., Back, K.J., \& Canter, D.D. (2005). The impact of employee training on job satisfaction and intention to stay in the hotel industry. Journal of Human Resources in Hospitality \& Tourism, 4(2), 99-118. https://doi.org/10.1300/J171v04n02_06

Combs, J., Liu, Y., Hall, A., \& Ketchen, D. (2006). How much do high-performance work practices matter? A meta-analysis of their effects on organizational performance. Personnel Psychology, 59(3), 501-528. https://doi.org/10.1111/j.1744-6570.2006.00045

Dewhurst, H., Dewhurst, P., \& Livesey, R. (2007). Tourism and hospitality SME training needs and provision: a sub-regional analysis. Tourism and Hospitality Research, 7, 131-143. https://doi.org/10.1057/palgrave.thr.6050037 
Fleming, J., Zinn, C., \& Ferkin, L. (2008). Bridging the gaps: Competencies students should focus on during their cooperative experience for employability. In The Australian Collaborative Education Network (Ed.), Work integrated learning (WIL): Transforming futures (pp. 155-163). Sydney, NSW, Australia: University of Technology Sydney. https://doi.org/10536/DRO/DU:30020961

Hartline, M.D., \& Ferrell, O.C. (1996). The management of customer-contact service employees: an empirical investigation. Journal of Marketing, 60(4), 52-70. https://doi.org/10.2307/1251901

Hearns, N., Devine, F., \& Baum, T. (2007). The implications of contemporary cultural diversity for the hospitality curriculum. Education Training, 49(5), 350-363. https://doi.org/ 10.1108/00400910710762922

Heskett, J.L., Sasser, W.E., \& Schlesinger, L.A. (1997). The Service Profit Chain. The Free Press, New York, NY.

Huselid, M.A., \& Becker, B.E. (2010). Bridging micro and macro domains: workforce differentiation and strategic human resource management. Journal of Management, 37(2), 421-428. https://doi.org/10.1177/0149206310373400

Jehanzeb, K., Rasheed, A., \& Rasheed, M. (2013). Organizational commitment and turnover intentions: impact of employee's training in private sector of Saudi Arabia. International Journal of Business and Management, 8(8), 79-90. https://doi.org/10.5539/ijbm.v8n8p79

Juan, M. (2017). Strategic human resources management research in hospitality and tourism A review of current literature and suggestions for the future. International Journal of Contemporary Hospitality Management, 29(1), 48-67. https://doi.org/10.1108/IJCHM-02-2016-0051

Kakeesh, D., Al-Weshah, G., \& Al-Ma'aitah, N. (2021). Maintaining Customer Loyalty Using Electronic Customer Relationship Management (E-CRM): Qualitative Evidence from Small Food Businesses in Jordan. Studies of Applied Economics, 39(7). https://doi.org/10.25115/eea.v39i7.4810

Kakeesh, D., \& Ahmad, A. (2020). How tourism quality creates satisfaction from the perspective of international tourists. Jordan Journal of Business Administration, 16(2): 473-495. https://doi.org/10.35516/0338-016-002-007

Kadiresan, V., Selamat, M., Selladurai, S., Ramendran, C., \& Mohamed, R. (2015). Performance appraisal and training and development of human resource management practices (HRM) on organizational commitment and turnover intention. Asian Social Science, 11(24), 162-176. https://doi.org/10.5539/ass.v11n24p162.

Kember, D., \& Leung, D. (2005). The influence of the teaching and learning environment on the development of generic capabilities needed for a knowledge-based society. Learning Environments Research, 8(3), 245-266. https://doi.org/10.1007/s10984-005-1566-5

Kyriakidou, O., \& Maroudas, L. (2010). Training and development in British hospitality, tourism and leisure SMEs. Managing Leisure, 15(1-2), 32-47. https://doi.org/10.1080/13606710903447998

Lee, P.C., \& Bugler, M.R. (2017). Training practices in the Hong Kong hotel industry: Managerial and executive perspectives. Journal of Human Resources in Hospitality \& Tourism, 16(1), 88-107. https://doi.org/10.1080/15332845.2016.1202066

Paauwe, J. (2009). HRM and performance: achievements, methodological issues and prospects. Journal of Management Studies, 46(1), 129-142. https://doi.org/10.1111/j.1467-6486.2008.00809.x

Ramendram, C.S., Supian, C.M.N., Kadiresan, V., Kumar, R., Mohamed, M.H., \& Rethinam, K. (2014). Promoting employment security through training for employability. International Journal of Management Sciences, 3(1), 45-55.

Rawashdeh, A. (2018). The impact of green human resource management on organizational environmental performance in Jordanian health service organizations. Management Science Letters, 8(10), 1049-1058. https://doi.org/10.5267/j.msl.2018.7.006

Rawashdeh, A.M., \& Karim Al-Adwan, I. (2012). The impact of human resource management practices on corporate performance: empirical study in Jordanian commercial banks. African Journal of Business Management, 6(41), 10591-10595. https://doi.org/10.5897/AJBM12.1169

Scheible, A.C.F., \& Bastos, A.V.B. (2013). An examination of human resource management practices' influence on organizational commitment and entrenchment. BAR - Brazilian Administration Review, 10(1), 57-76. https://doi.org/10.1590/S1807-76922012005000011

Sergeant, A., \& Frenkel, S. (2000). When do customer contact employees satisfy customers?.Journal of Service Research, (3), 18-34. https://doi.org/10.1177/109467050031002

Tracey, J. (2014). A review of human resources management research: the past 10 years and implications for moving forward. International Journal of Contemporary Hospitality Management, 26(5), 679-705. https://doi.org/10.1108/IJCHM-02-2014-0056

Tracey, J., \& Tews, M. (2004). An empirical investigation of the relationships among climate, capabilities, and unit performance. Journal of Hospitality and Tourism Research, 28(3), 298-312. https://doi.org/10.1177/1096348003256602

Yang, H., Sanders, K., \& Bumatay, C. (2012). Linking perceptions of training with organizational commitment: the moderating role of selfconstrual. European Journal of Work and Organizational Psychology, 21(1), 125-149. https://doi.org/10.1080/1359432X.2010.546948

Young-Thelin, L., \& Boluk, K. (2012). A case study of human resource practices in small hotels in Sweden. Journal of Human Resources in Hospitality \& Tourism, 11(4), 327-353. https://doi.org/10.1080/15332845.2012.690683

Zehrer, A., \& Mössenlechner, C. (2009). Key competencies of tourism graduates: The employers' point of view. Journal of Teaching in Travel and Tourism, 9(3), 266-287. https://doi.org/10.1080/15313220903445215

Zhao, X., Zhan, J., \& Namasivayam, K. (2004). Factors affecting training success in China. Journal of Human Resources in Hospitality \& Tourism, 3(1), 89-105. https://doi.org/10.1300/J171v03n01_08

*** Jordan Strategy Forum. (2020). Enhancing the Competitiveness of the Tourism Sector in Jordan: Prospect and Adaptation to New Trends. Jordan, accessed 11-11-2020. www.jsf.go

*** USAID (2020). Building Economic Sustainability Through Tourism Project; Providing Industry with Tourism Data to Support Tourism Resilience: Recovery Planning from COVID-19, Jordan.

Article history: Received: 17.08.2021 Revised: 16.11.2021 Accepted: 24.12.2021 Available online: 10.01 .2022 